REVIEW ARTICLE

\title{
Effects of aerobic physical activity to cardio-respiratory fitness of the elderly population: systematic overview
}

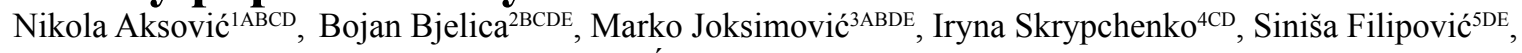
Filip Milanovićs ${ }^{5 \mathrm{DE}}$, Bojan Pavlovićéc ${ }^{\mathrm{AB}}$, Bojan Ćorluka ${ }^{6 \mathrm{DE}}$, Radomir Pržulj ${ }^{\mathrm{CDE}}$

${ }^{1}$ University of Niš, Serbia

${ }^{2}$ University of East Sarajevo, Bosnia and Herzegovina

${ }^{3}$ Football club National, Montenegro

${ }^{4}$ Dnipropetrovs'k State University of Internal Affairs, Ukraine

${ }^{5}$ University of Belgrade, Serbia

${ }^{6}$ University of East Sarajevo, Bosnia and Herzegovina

Authors' Contribution: A - Study design; B - Data collection; C - Statistical analysis; D - Manuscript Preparation; E - Funds Collection.

\section{Abstract}

Purpose:

Aerobic training is effective manner of exercising aimed at improving cardio-respiratory fitness of young people. However, its effects to the elderly population (over the age of 60), depending on characteristics of the participant (gender, health status, lifestyle, etc.), is still unclear. Aim of this research is systematic overview of the available literature dealing with the topic of effects of aerobic training to cardiorespiratory fitness of the elderly population over the age of 60, depending of gender (male/female), BMI (overweight/normal weight), lifestyle (active/sedentary), health status (diabetes/hypertension/ metabolic syndrome).

Material: $\quad$ Total number of papers with published research results which met the criteria was 32. Walking is effective manner of exercising which influences improvement of maximum oxygen consumption (mean value: \pm SD:12.91 $\pm 7.40 \%$ ). Introduction of activities with greater impact (bicycle and jogging) provides more effect to the cardio-respiratory fitness (mean value: \pm SD:14.28 $\pm 7.48 \%$ ).

Results: $\quad$ Aerobic training intensity level (moderate vs. high) makes no significant difference to the adaptive response of the cardio-respiratory fitness in elderly population. Training in duration of 6 weeks may significantly influence increase in maximum oxygen consumption, but longer training duration, however, has better effect. Endurance training has similar effects to improvement of cardio-respiratory fitness in both men and women. On the other hand, it seems that active people have lower adaptive response in comparison to sedentary people ( $8.3 \%$ vs. $18.84 \%)$. Effect is similar between overweight and normal weight participants ( $18.48 \%$ vs. $8.6 \%$ ). Positive influence of aerobic training was also observed in participants with hypertension, metabolic system and diabetes type 2 .

Conclusions: $\quad$ Results clearly suggest benefits of aerobic training on cardio-respiratory fitness of elderly population. The effect may, however, vary depending of duration, type of activity, as well as characteristics of the sample.

Keywords: $\quad$ training, sedentary, VO2max, walking, health, HRmax.

\section{Introduction}

Epidemiological studies indicate tight connection between exercising, health and fitness and the role of lifestyle to health of general population $[1,2]$. Term physical fitness is related to certain level of being in physical shape. Additionally, it is used as synonym to certain types of exercising. Important fitness component linked to health status is cardio-respiratory fitness [3] . Cardio-respiratory fitness is the ability of cardio-vascular system and respiratory system to maintain oxygen supply to engaged muscles in duration of prolonged physical activity, as well as the ability of muscles to provide required energy in aerobic processes [4]. Maximum oxygen consumption $\left(\mathrm{VO}_{2 \max }\right)$ is the best indicator of aerobic capabilities of the organism and functional ability of cardio-vascular system, respiratory system and

\footnotetext{
(c) Nikola Aksović, Bojan Bjelica, Marko Joksimović,

Iryna Skrypchenko, Siniša Filipović, Filip Milanović, Bojan Pavlović, Bojan Ćorluka, Radomir Pržulj, 2020

doi:10.15561/26649837.2020.0501
}

tissue to use the available oxygen [5], which all reduces with aging. After the age of 25-30 sedentary people experience reduction of $\mathrm{VO}_{2 \max } 8-15 \%$ per decade [6] . Reduced capability to perform everyday activities after the age of 60 is caused by gradual reduction of $\mathrm{VO}_{2 \max }[8]$. Aerobic training or endurance training is recommended for improving cardio-respiratory fitness and health benefits of elderly population. It may be defined as activity in minimal duration of 20 minutes where values of heart rate frequency are $60-80 \%$ of maximum heart rate frequency $\left(\mathrm{HR}_{\max }\right)$ [9] Previously performed metaanalyses confirmed the positive effect of training to $\mathrm{VO}_{2 \max }$ in elderly population. Despite important results obtained $[10,11]$ value of moderator in meta-regression analysis took value of 50 for independent variable age. Value for elderly people was $(>50)$, which is an indicator of high variability among the participants. In the aforementioned study was also used common statistical method for calculation of the magnitude of effect of 
various types of training (aerobic training, training with the load, etc.) to cardio-respiratory fitness. Second metaanalysis [10] included papers published in the period 1980-2002 and due to lack of available data, metaregression analysis was not performed for the following variables: gender (male/female), BMI (overweight/ normal weight), lifestyle (active/sedentary), health status. Up to date, the number of conducted research on the topic of effects of aerobic training to elderly population is low and requires information update. More sophisticated tools for assessment of performances and improved quality of research have also been developed. Therefore, aim of research is systematic overview of the available literature linked to effects of aerobic training to cardiorespiratory fitness of elderly population over the age of 60 , depending of gender (male/female), BMI (overweight/ normal weight), lifestyle (active/sedentary), health status (diabetes/hypertension/metabolic syndrome).

\section{Material and methods}

Data sources and search strategy

For the purpose of searching the available literature, following data bases were used: PubMed, MEDLINE, Google Scholar, ScienceDirect, ERIC from 1986 to August 2016. Searching was performed using following terms (individually or in combination): physical activity, cardio-respiratory fitness, older adults, aerobic training, $\mathrm{VO}_{2 \text { max }}$ effects, endurance training, walking, running, elderly. Searching strategy was modified for each electronic database, where it was possible, with the aim of increasing sensitivity. All the papers and abstracts were evaluated for selection of potential papers to be included in the systematic overview. Lists of references and original research were also included in the analysis. One author performed literature search (EC). Relevant studies were obtained after detailed search if they met the criteria. The criteria are described in the following section.

Inclusion criteria

Type of study

Controlled randomised and non-randomised studies about effects of aerobic training to cardio-respiratory fitness in English language were included in the analysis.

\section{Sample}

Included participants are men and women aged over 60 regardless of lifestyle (active/sedentary), BMI (overweight/normal weight), health status (diabetes, metabolic syndrome, hypertension).

\section{Type of intervention}

Research establishing the effect of aerobic training.

Type of output results

Studies were included if the results present influence of aerobic training to $\mathrm{VO}_{2 \max }$ before and after aerobic training.

\section{Exclusion criteria}

Exclusion criteria were: 1) studies in languages other than English; 2) Age of participants under $60 ; 3$ ) combination of aerobic training with training under load.

Data acquisition

Formatused fordataacquisitionwasPICO(Participants,
Intervention, Comparison or control group, Outcomes) [12]: participants (and their health status, gender, BMI, lifestyle age), sample size, comparison of groups, training program (frequency, duration, type of activity, intensity) and acquired results (absolute and relative $\mathrm{VO}_{2 \max }$ ). Data extraction was performed using Cochrane Consumers and Communication Review Group's data extraction protocol. Selection and assessment of data was performed by single author in order to maintain precision and to be comprehensive. All the selected papers were assessed in detail to collect required data. Authors of included papers were not contacted for missing data.

\section{Results}

In search results there were 785 identified potentially relevant studies, and 15 more after covering the references. After removal of double papers and abstracts there were 88 papers remaining. Upon completion of assessment of whole texts only 32 papers remained where all the criteria were met (Fig 1).

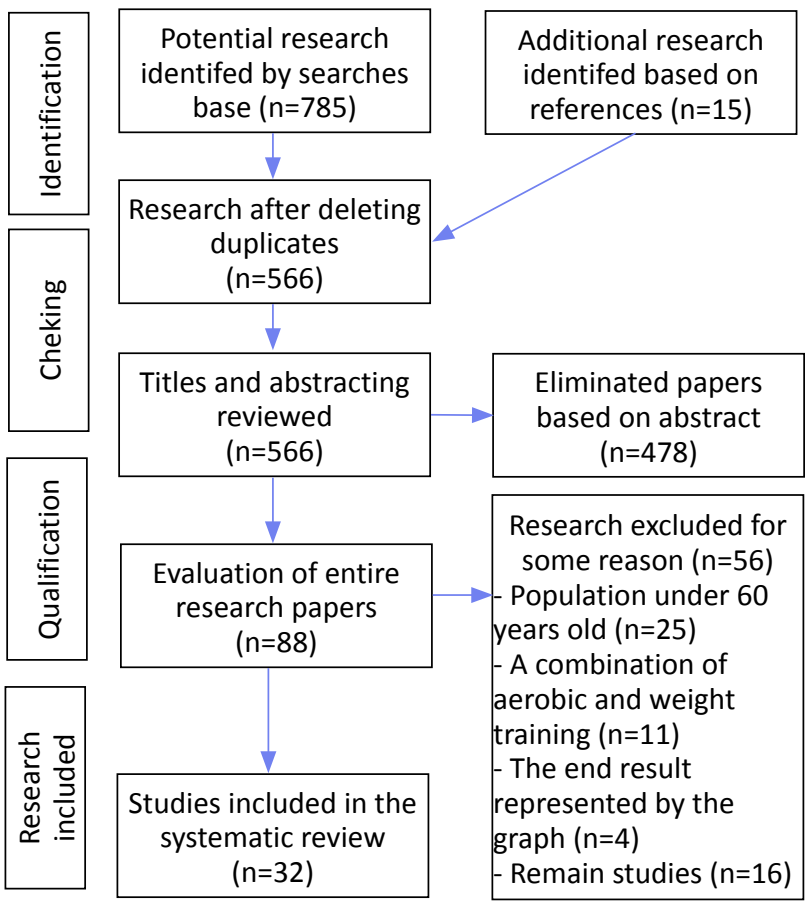

Figure 1. Flow Diagram

\section{Aerobic training}

Aerobic physical training triggers positive adaptive response to absolute and relative $\mathrm{VO}_{2 \max }$. It seems that the simplest and most acceptable form of aerobic training is walking. Choice of this type of physical activity can be prescribed to less chance of injury, no supervision required and universal availability, which is why majority of authors researched influence of aerobic training in this training regime $[13,16,20,23]$. Results of this systematic overview suggest that walking significantly improves absolute $\mathrm{VO}_{2 \max }$ values. Average improvement is $12.91 \pm 7.40 \%$ (range $1 \%-27 \%$ ). Additionally, results of previous meta-analysis confirmed significant effect of walking to cardio-respiratory fitness in healthy sedentary population [25]. Contemporary studies [26, 27, 30, 


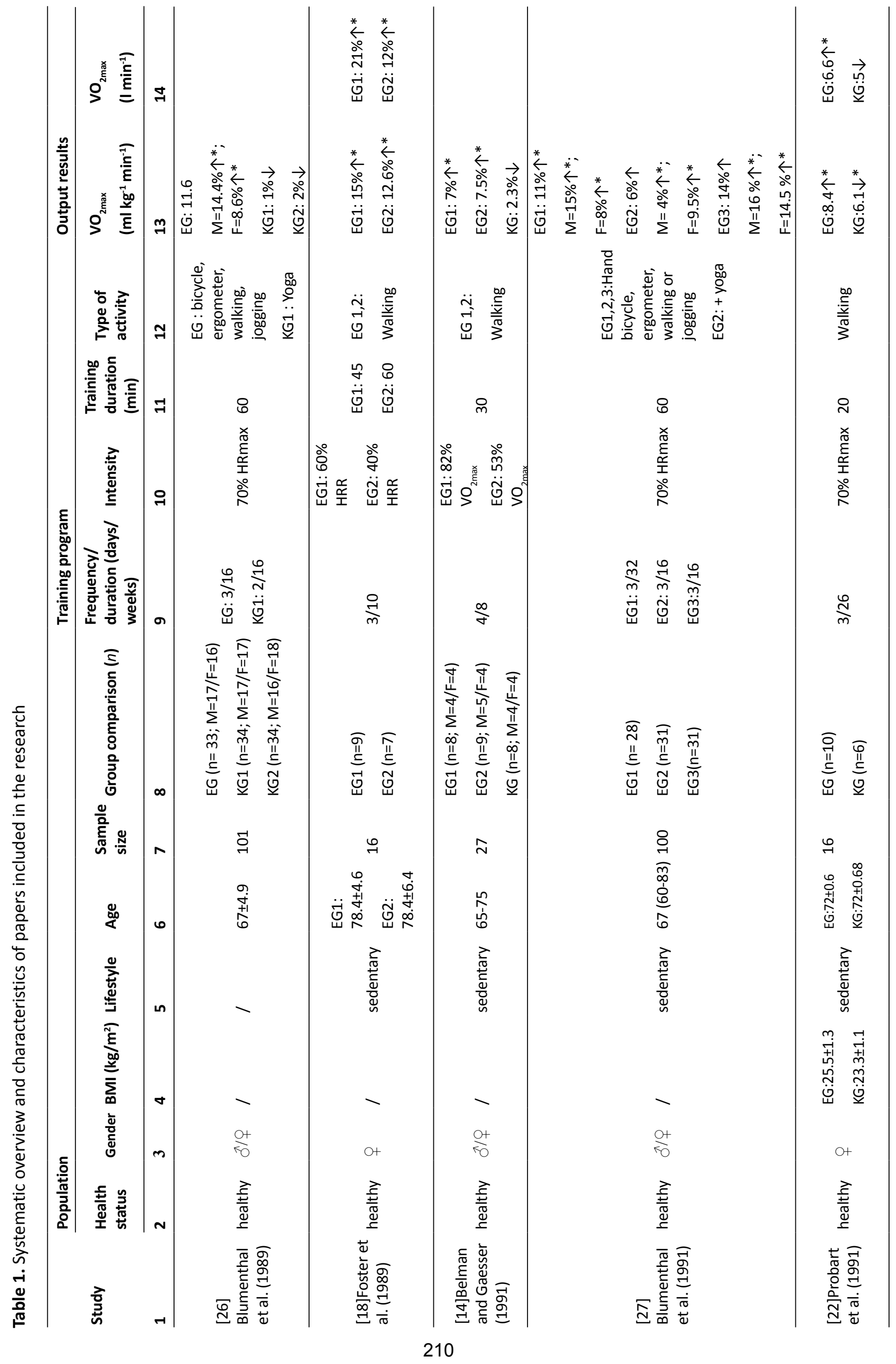




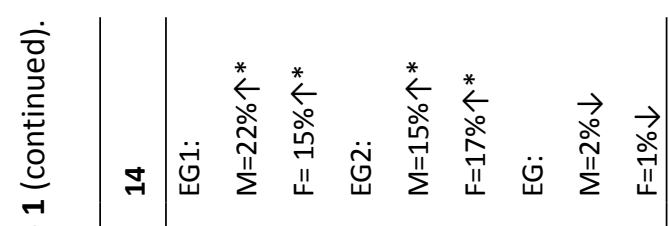

$\frac{\frac{0}{0}}{\sqrt{0}}$

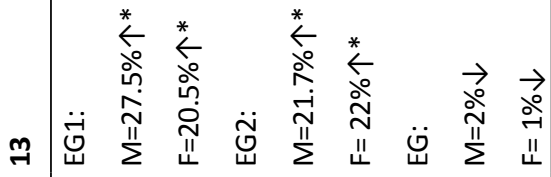

₹

$\exists$

욱

$a$

$\infty$

N

$\bullet$

in

N

N
箩咅

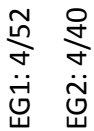

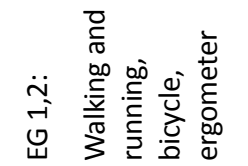

웅
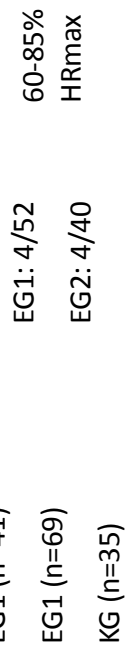

年

参

童

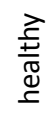

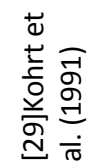

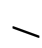

$\frac{0+}{r_{0}}$

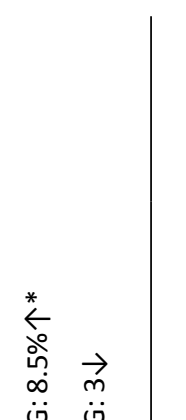

نु

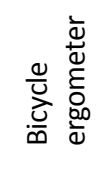

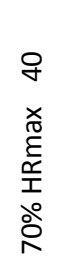

앙

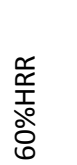

$\stackrel{6}{7}$

$\underset{\frac{n}{2}}{3}$

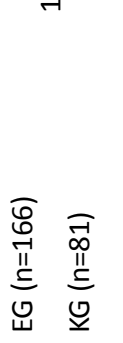

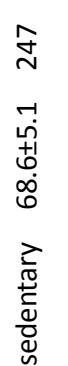

$\mid-1$

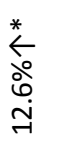

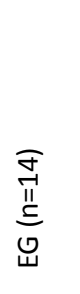

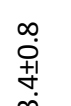

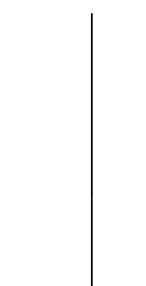

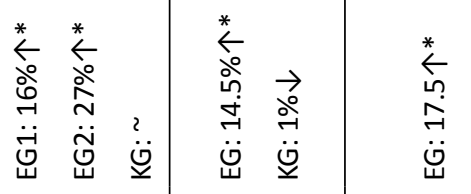

$\stackrel{\frac{00}{5}}{\frac{\sqrt[n]{m}}{3}}$

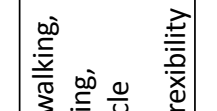

产

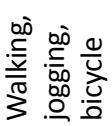

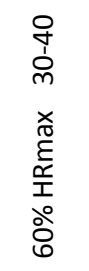

q

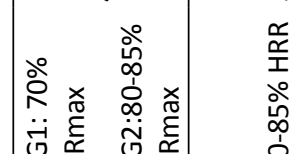

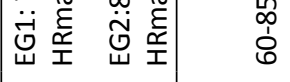

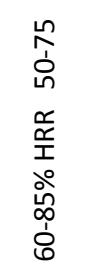

$\underset{\operatorname{ก}}{2}$

政

$\stackrel{\text { กี }}{\stackrel{2}{\pi}}$

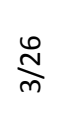

$\stackrel{\infty}{\stackrel{m}{m}}$

$\stackrel{\infty}{n}$

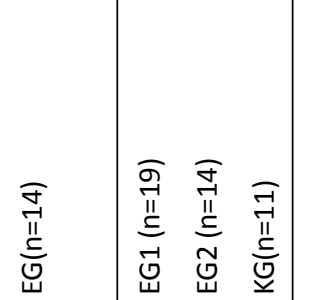

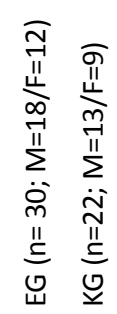

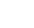

(1)

0

$\underset{4}{A}$

氽

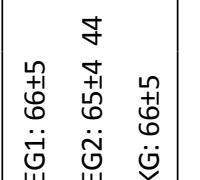

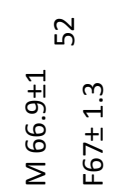

$\stackrel{2}{\sim}$

m

홍

苞

龺

\begin{tabular}{l|l}
- & - \\
$\frac{1}{2}$ & $0+$
\end{tabular}

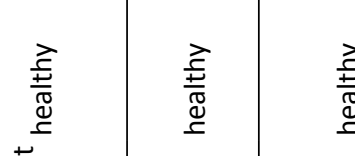

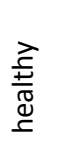

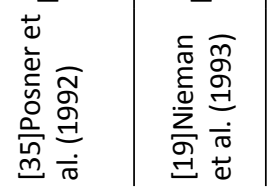

竞离 


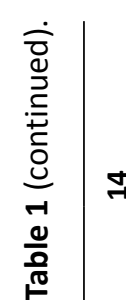

$m \quad$ 岀

$\approx \quad \frac{\sqrt[00]{\frac{00}{3}}}{3}$

7

$\Rightarrow$

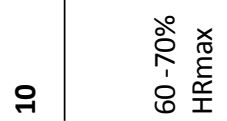

$a \quad \frac{N}{m}$

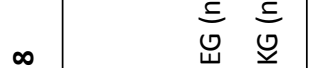

-

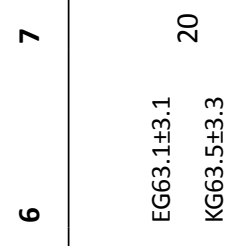

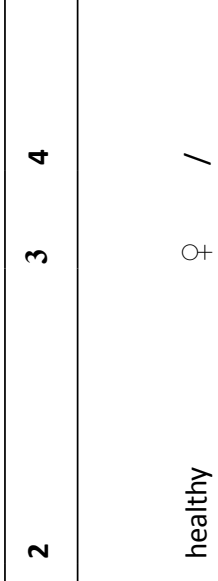

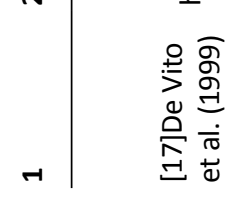

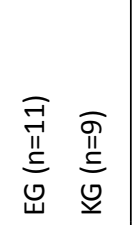

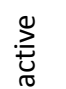

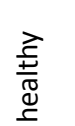

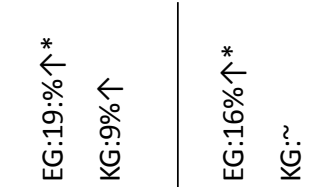

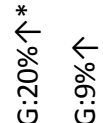

芦

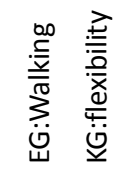

q

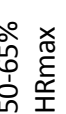

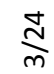

$\stackrel{\text { d }}{m}$

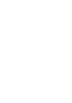

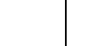

จิ



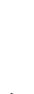

-

$\frac{1}{20}$

$\frac{\mathrm{O}+}{\mathrm{s}}$

站

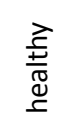

造

.0

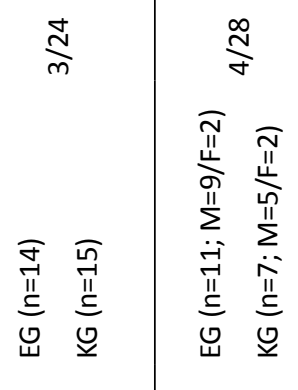

$\stackrel{*}{\leftarrow}$

芦芦

$\frac{0}{\overline{0}}$

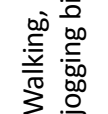

0
0
$\dot{q}$

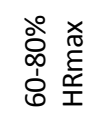

$\stackrel{\infty}{\rightarrow}$

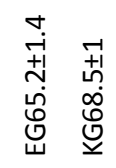

恋

ํ.

岀

$\frac{\mathrm{O}+}{\sqrt{5}}$

这

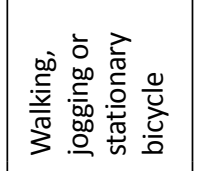

웅

ฏ̊ำ

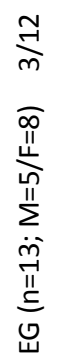

$\stackrel{m}{\sim}$

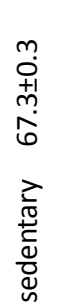

茫

$\frac{0+}{50}$

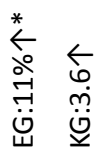

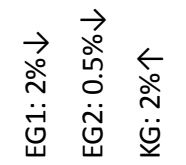

$\stackrel{*}{\leftarrow} \stackrel{*}{\leftarrow}$

ते

离

垴.

竞亭

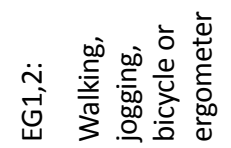

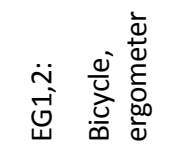

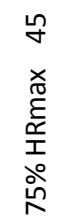

8

요

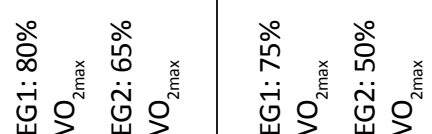

$\stackrel{\infty}{N}$

昌

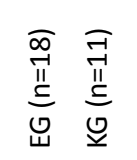

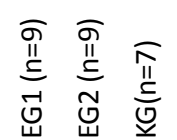

고

$\stackrel{n}{\sim}$

म

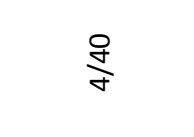

ิㅗำ

垔 $\bar{m}$ 吕

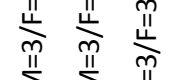

$\sum_{i=0} \sum_{i=1}^{11}$

î

氙 勇

$\stackrel{\infty}{\sim}$

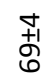

章

$\stackrel{m}{m} \stackrel{0}{m}$

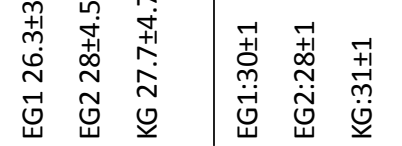

o+

$\frac{\mathrm{O}+}{\mathrm{s}}$

亲

孪

$$
\text { (n) }
$$

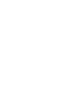

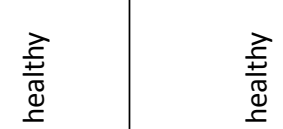

冚要

竞苋

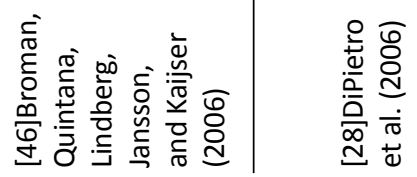

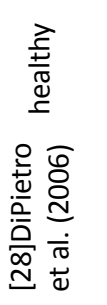

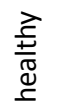

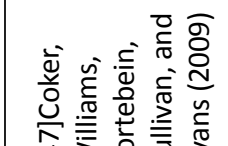




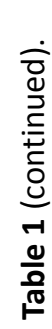

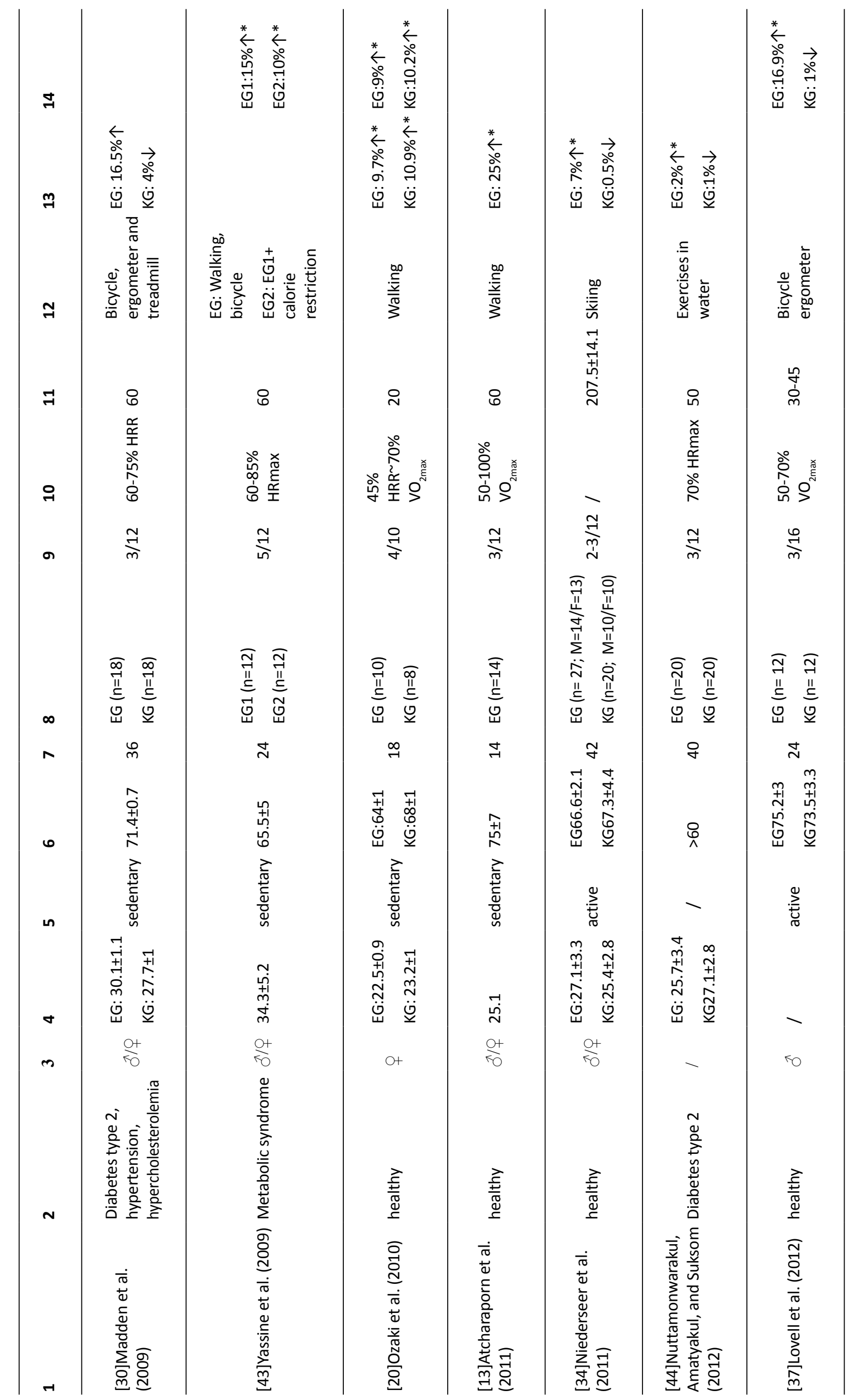




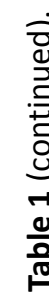

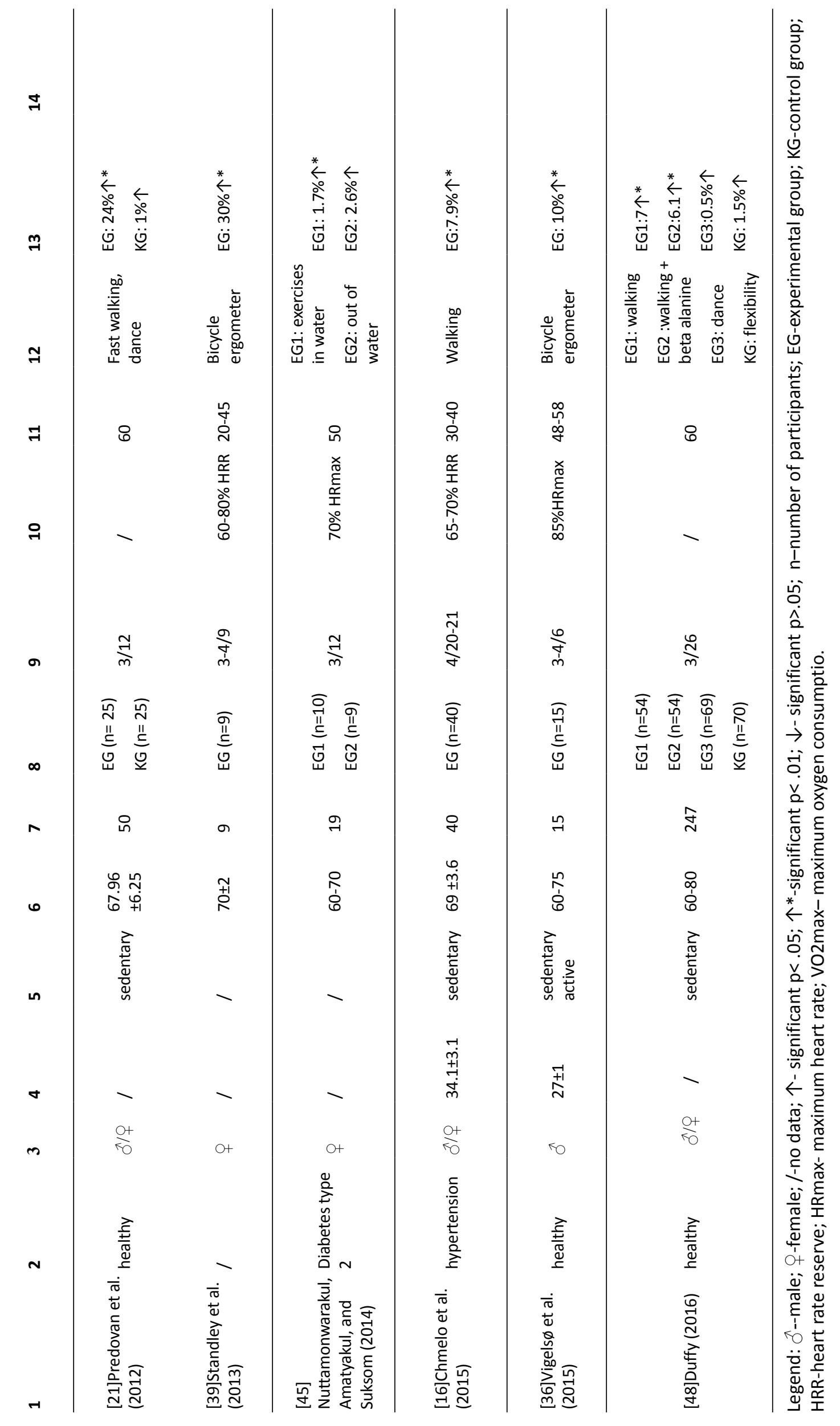


31] also suggest that aerobic training may have more benefits to $\mathrm{VO}_{2 \max }$ when complemented with high impact activities such as jogging and bicycle ergometer (mean value \pm standard deviation $14.28 \pm 7.48 \%$ ). Skiing is yet another form of physical activity which reduces possibility of developing cardio-vascular conditions [34], but it is recommended to more active people due to risk of injury. Belman, \& Gaesser [14] and Foster, et al., [18] state that in elderly population there is no difference, or there is slight difference, in adaptation to endurance training with various intensities (moderate vs. high intensity). These findings are to great extent in line with previous meta-analysis [10]. Results indicate that $60 \%$ intensity of $\mathrm{VO}_{2 \max }$ is adequate stimulus for improving cardiorespiratory endurance of elderly population. In addition to that, this overview revealed that trainings at low frequency (once a week) have positive effect to aerobic endurance [35]. Also, endurance training in duration of 6 weeks may significantly influence the increase in $\mathrm{VO}_{2 \max }(10 \%)$ [36]. However, numerous research performed validated that long duration endurance training ( $>16$ weeks) can have greater effect to cardio-respiratory system $[15,29,37,32]$.

\section{Discussion}

There are numerous morphological and physiological differences between men and women connected to cardiorespiratory fitness [38]. Women have lower blood volume, lower count of red blood cells, lower haemoglobin, which all leads to lower oxygen capacity and hence ability to increase arterial and vain differences in $\mathrm{O}_{2}$ Despite number of physiological differences, it seems that aerobic training contributes significant increase in $\mathrm{VO}_{2 \max }$ levels in both men and women $[18,37,39,36]$. Women show similar level of adaptation to one stimulus as elderly men [26, 29]. Similar adaptive response (increase in $\left.\mathrm{VO}_{2 \max }\right)$ to endurance training in men was prescribed to increase in maximum minute volume (2/3) and increase in arterial-vein oxygen difference (1/3). On the other hand, women expressed no central adaptation, but only peripheral, due to the fact that increase in $\mathrm{VO}_{2 \max }$ levels was caused by increase in arterial-vein $\mathrm{O}_{2}$ difference [40], whereas the increase of arterial-vein $\mathrm{O}_{2}$ difference was caused by capilarisation of skeletal muscles and activity of mitochondrial enzymes [41]. It seems that hormones may influence lack of increase of minute and stroke volume, because women in post-menopause develop no hypertrophy of left chamber [40]. Changes contributing reduction in $\mathrm{VO}_{2 \max }$ level are numerous. $\mathrm{VO}_{2 \max }$ is very sensitive to changes in individual's lifestyle (active/ sedentary). Cardio-vascular system oxygen transport capacity reduces with reduction in physical activity [42], and it increases as response to endurance training $[16,39$, 36]. Niederseer et al. [34] performed research on influence of skiing to cardio-respiratory system of healthy elderly participants. In the research they applied training program in duration of 12 weeks where daily activity lasted for 3.5 hours twice or three times a week. Upon completion of three months of training, experimental group had significant increase in absolute $\mathrm{VO}_{2 \max } 7 \%$, whereas no changes had been observed in the control group. Positive effect of aerobic exercising was also presented by Lovell, et al., [37]. Research authors stated that endurance training in duration of 16 weeks, with intensity 50-70 $\mathrm{VO}_{2 \max }$, three times a week significantly increases relative $\mathrm{VO}_{2 \max }(16.9 \%)$. However, training programs of similar capacity with similar load intensity lead to no improvement whatsoever in $\mathrm{VO}_{2 \max }$ of elderly women [17]. Authors found that the reason behind failure to have cardio-vascular adaptation was due to insufficiently long maintaining of intensity of physical activity in duration of training. Studies dealing with the effect of aerobic training to healthy active people show different findings, possibly due to type of physical activity performed as well as maintaining the intensity of physical activity in duration of training. Average improvement rate for active elderly individuals was $8.3 \%$. However, these results should be interpreted with caution due to relatively small number of studies performed. People with sedentary lifestyle showed better adaptation to endurance training (mean value of absolute $\mathrm{VO}_{2 \max } 14.84 \%$ ), probably due to lower baseline fitness. In majority of research sample consisted of healthy participants $(77 \%)$, whereas other research $(23$ $\%$ ) had patients with diabetes, hypertension or metabolic syndrome (see Table 1). Number of healthy participants was 1337 , versus 177 ( 1 research had no health status included in the parameters $n=9$ ). Despite small number of research dealing with effect of aerobic training to people with hypertension, similar positive effect to cardiorespiratory system to healthy individuals was observed $[16,30,32]$. The effect was also observed in patients with metabolic syndrome [43]. On the other hand, even though participants with diabetes type 2 showed statistically significant increase in $\mathrm{VO}_{2 \max }$ in response to aerobic training in water, this increase is lower than in case of healthy individuals (around $2 \%$ vs. $15 \%$ ) [44, 45]. Factor which contributes reduction in $\mathrm{VO}_{2 \max }$ is higher weight, especially in form of fat tissue. It seems that the effect of aerobic training in overweight individuals (BMI $>30)$ is higher in comparison to individuals with normal weight ( 18.48 vs. $8.6 \%$ absolute $\mathrm{VO}_{2 \max }$ ). Better adaptive response to aerobic training may also be prescribed to lower baseline fitness, as in case of inactive individuals. However, lower baseline fitness of overweight individuals is caused by higher fat mass.

\section{Conclusion}

In this systematic overview we have briefly discussed practical application of aerobic training to elderly people over the age of 60 , with focus on achieved effect depending of characteristics in the sample. In that sense we have to take into consideration that participants in the used studies were overweight (BMI>30), with hypertension, diabetes type 2 , metabolic syndrome, with different lifestyles (active/sedentary) and gender. Despite all that, results suggest clear benefits of aerobic training to cardio-respiratory system. Certain discrepancies may however be prescribed to characteristics of the sample. American College of Sport Medicine drafted guidelines 
for improving cardio-respiratory fitness. In line with the guidelines, training should be held three times a week in duration 30-40 minutes with minimum intensity 50\% $\mathrm{VO}_{2 \max }$ or $60 \%$ Hrmax. As it has already been observed, aerobic training of such intensity seems to be strong incentive for improvement of cardio-respiratory fitness in aging process. Available results suggest that training in duration of only 6 weeks may significantly influence increase in $\mathrm{VO}_{2 \max }$ [36], but that trainings in longer duration ( $>16$ weeks) contribute to even greater extent to the cardio-respiratory fitness $[7,18,22,33]$. Certain limitations of the systematic overview should be stated here. There are limitations in the external validity because majority of studies included in the overview examined influence of aerobic training to healthy individuals, whereas smaller number of studies was performed on individuals with hypertension, diabetes or metabolic syndrome. Further research on effects of aerobic training to active elderly population is required. Hence, limited number of researches conducted in required sample makes difficult drafting final conclusions. It should also be emphasized that average improvement of cardio-respiratory fitness depending on characteristics of participants was expressed using absolute oxygen consumption, due to variability among studies. Despite limitations linked with effects of aerobic training of individuals with different health status, lifestyle and gender, endurance training can be recommended as safe and effective form of exercising used for improvement of cardio-respiratory fitness of elderly population.

\section{Funding}

This research received no external funding.

\section{Conflicts of Interest}

The authors declare no conflict of interest.

\section{References}

1. Dustman RE, Ruhling RO, Russell EM, Shearer DE, Bonekat HW, Shigeoka JW, et al. Aerobic exercise training and improved neuropsychological function of older individuals. Neurobiology of Aging, 1984;5:35-42. https://doi.org/10.1016/0197-4580(84)90083-6

2. Izquierdo-Porrera AM, Gardner AW, Powell CC, Katzel LI. Effects of exercise rehabilitation on cardiovascular risk factors in older patients with peripheral arterial occlusive disease. Journal of Vascular Surgery. 2000; 31(4): 670-677. https://doi.org/10.1067/mva.2000.104422

3. Warburton DE, Nicol CW, Bredin SS. Prescribing exercise as preventive therapy. Canadian Medical Association Journal. 2006; 174(7): 961-974. https://doi.org/10.1503/cmaj.1040750

4. Snell PG, Stray-Gundersen J, Levine BD, Hawkins MN, Raven PB. Maximal Oxygen Uptake as a Parametric Measure of Cardiorespiratory Capacity: Medicine \& Science in Sports \& Exercise 2007;39:103-7. https://doi.org/10.1249/01.mss.0000241641.75101.64

5. Radovanović D. Practicum in Physiology: for students of the Faculty of Sport and Physical Education. Faculty of Sport and Physical Education; 2012. (In Serbian).

6. Spina RJ. 10 Cardiovascular Adaptations to Endurance Exercise Training in Older Men and Women. Exercise and Sport Sciences Reviews. 1999; 27(1): 317-332. https://doi.org/10.1152/jappl.1993.75.2.849

7. Stewart KJ. Physical activity and aging. Annals of the New York Academy of Sciences. 2005; 1055(1): 193-206. https://doi.org/10.1196/annals.1323.029

8. Posner J, McCully K, Landsberg L, Sands L, Tycenski P, Hofmann $M$, et al. Physical determinants of the indipendence in mature women. Archives of Physical Medicine and Rehabilitation. 1995; 76(4): 373-380. https://doi.org/10.1016/S0003-9993(95)80664-4

9. Carter JB, Banister EW, Blaber AP. Effect of endurance exercise on autonomic control of heart rate. Sports Medicine. 2003; 33(1): 33-46. https://doi.org/10.2165/00007256-200333010-00003

10.Huang G, Gibson CA, Tran ZV, Osmess WH. Controlled endurance exercise training and VO2max changes in older adults: a meta-analysis. Preventive Cardiology. 2005; 8(4): 217-225. https://doi.org/10.1111/j.0197-3118.2005.04324.x

11.Lin X, Zhang X, Guo J, Roberts CK, McKenzie S, Wu WC, Liu S, Song Y. Effects of exercise training on cardiorespiratory fitness and biomarkers of cardiometabolic health: a systematic review and metaanalysis of randomized controlled trials. Journal of the American Heart Association. 2015; 4(7): e002014. https://doi.org/10.1161/JAHA.115.002014

12.Liberatia A, Altman DG, Tetzlaff J, Mulrow C, Gotzsche PC, Ioannidis JP, Clarke M, Devereaux PJ, Kleijnen J, Moher D. The PRISMA statement for reporting systematic reviews and meta-analyses of studies that evaluate health care interventions: explanation and elaboration. Annals of Internal Medicine. 2009; 151(4): 65-94. https://doi.org/10.1136/bmj.b2700

13.Atcharaporn L, Nadine MF, Atif BA, David RP. The Respiratory Exchange Ratio Is Higher in Older Subjects, but Is Reduced by Aerobic Exercise Training. International Journal of Endocrinology and Metabolism. 2011; 1:264-270. https://doi.org/10.5812/kowsar.1726913X.1789.

14.Belman MJ, Gaesser GA. Exercise training below and above the lactate threshold in the elderly. Medicine and Science in Sports and Exercise. 1991; 23(5): 562- 568. https://doi.org/10.1249/00005768-199105000-00008

15.Braith RW, Pollock ML, Lowenthal DT, Graves JE, Limacher MC. Moderate-and high-intensity exercise lowers blood pressure in normotensive subjects 60 to 79 years of age. The American Journal of Cardiology. 1994; 73(15): 1124-1128. https://doi.org/10.1016/0002-9149(94)90294-1

16.Chmelo EA, Crotis CI, Newman JC, Brinkley TE, Lyles MF, Leng $X$, et al. Heterogeneity of physical function responses to exercise training in older adults. Journal of the American Geriatrics Society.2015; 63(3), 462-469. https://doi.org/10.1111/jgs.13322

17.De Vito G, Bernardi M, Forte R, Pulejo C, Figura F. Effects of a low-intensity conditioning programme on $\mathrm{V}^{\cdot} \mathrm{O} 2 \mathrm{max}$ and maximal instantaneous peak power in elderly women. European Journal of Applied Physiology and Occupational Physiology. 1999; 80(3): 227-232. https://doi.org/10.1007/s004210050586

18.Foster VL, Hume GJ, Byrnes WC, Dickinson AL, Chatfield SJ. Endurance training for elderly women: moderate vs low intensity. Journal of Gerontology. 1989; 44(6): M184-M188. 
https://doi.org/10.1093/geronj/44.6.m184

19.Nieman DC, Warren BJ, O'Donnell KA, Dotson RG, Butterworth DE, Hensen DA. Physical activity and serum lipids and lipoproteins in elderly women. Journal of the American Geriatrics Society. 1993; 41(12): 1339-1344. https://doi.org/10.1111/j.1532-5415.1993.tb06485.x

20.Ozaki H, Sakamaki M, Yasuda T, Fujita S, Ogasawara R, Sugaya $\mathrm{M}$, et al. Increases in thigh muscle volume and strength by walk training with leg blood flow reduction in older participants. The Journals of Gerontology Series A: Biological Sciences and Medical Sciences. 2010; 66A(3): 257-263. https://doi.org/10.1093/gerona/glq182

21.Predovan D, Fraser SA, Renaud M, Bherer L. The effect of three months of aerobic training on stroop performance in older adults. Journal of Aging Research. 2012; 1-7. https://doi.org/10.1155/2012/269815

22.Probart C, Notelovitz M, Martin D, Khan F, Fields C. The effect of moderate aerobic exercise on physical fitness among women 70 years and older. Maturitas. 1991; 14(1): 49-56. https://doi.org/10.1016/0378-5122(91)90147-I

23. Warren B, Nieman D, Dotson R, Adkins C, O`Donnell K, Haddock B, et al. Cardiorespiratory responses to exercise training in septuagenarian women. International Journal of Sports Medicine. 1993; 14(2): 60-65.

24.Woods JA, Ceddia M, Wolters B, Evans J, Lu Q, McAuley E. Effects of 6 months of moderate aerobic exercise training on immune function in the elderly. Mechanisms of Ageing and Development. 1999; 109(1): 1-19. https://doi.org/10.1016/s0047-6374(99)00014-7

25.Murphy MH, Nevilla AM, Murtagh EM, Holder RL. The effect of walking on fitness, fatness and resting blood pressure: a meta-analysis of randomised, controlled trials. Preventive Medicine. 2007; 44(5): 377-385. https://doi.org/10.1016/j.ypmed.2006.12.008

26. Blumenthal JA, Eemry CF, Madden DJ, George LK, Coleman RE, Riddle MW, McKee DC, Reasoner J, Wolliams RS. Cardiovascular and behavioral effects of aerobic exercise training in healthy older men and women. Journal of Gerontology. 1989; 44(5): M147-M157. https://doi.org/10.1093/geronj/44.5.m147

27.Blumenthal, JA, Emercy CF, Madden DJ, Schniebolk S, Riddle MW, Cobb FR, Higginbotham M, Coleman RE. 1991: Effects of exercise training on bone density in older men and women. Journal of the American Geriatrics Society. 1991; 39(11): 1065-1070. https://doi.org/10.1111/j.1532-5415.1991.tb02870.x

28.DiPietro L, Dziura J, Yeckel CW, Neufer PD. Exercise and improved insulin sensitivity in older women: evidence of the enduring benefits of higher intensity training. Journal of Applied Physiology. 2006; 100(1): 142-149. https://doi.org/10.1152/japplphysiol.00474.2005

29.Kohrt WM, Malley MT, Coggan AR, Spina RJ, Ogawat T, Ehsani A, Bourey RE, Martin WH, Holloszy J. Effects of gender, age, and fitness level on response of VO2max to training in 60-71 yr olds. Journal of Applied Physiology. 1991; 71(5): 2004-2011. https://doi.org/10.1152/jappl.1991.71.5.2004

30.Madden KM, Lockhart C, Cuff D, Potter TF, Mneilly GS. Short-term aerobic exercise reduces arterial stiffness in older adults with type 2 diabetes, hypertension, and hypercholesterolemia.Diabetes Care. 2009;32(8):1531-1535. https://doi.org/10.2337/dc09-0149

31.Pruchnic R, Katsiarasa A, He J, Kelley DE, Winters C, Goodpaster BH. Exercise training increases intramyocellular lipid and oxidative capacity in older adults. American Journal of Physiology-Endocrinology and Metabolism. 2004; 287(5):

E857-E862.

https://doi.org/10.1152/ajpendo.00459.2003

32.Turner MJ, Spina RJ, Kohrt WM, Ehsani AA. Effect of endurance exercise training on left ventricular size and remodeling in older adults with hypertension. The Journals of Gerontology Series A: Biological Sciences and Medical Sciences. 2000; 55(4): 245-251. https://doi.org/10.1093/gerona/55.4.m245

33. VitielloI MV, Wilkinson CW, Merriam GR, Moe KE, Prinz PN, Ralph DD, Colasurdo EA, Schwartz RS. Successful 6-month endurance training does not alter insulin-like growth factor-I in healthy older men and women. The Journals of Gerontology Series A: Biological Sciences and Medical Sciences. 1997, 52(3): 149-154. https://doi.org/10.1093/gerona/52a.3.m149

34.Niederseer D, Ledl-Kurkowski E, Kvita K, Patsch W, Dela F, Mueller E, Niebauer J. Salzburg Skiing for the Elderly Study: changes in cardiovascular risk factors through skiing in the elderly. Scandinavian Journal of Medicine \& Science in Sports. 2011; 21(1): 47-55. https://doi.org/10.1111/j.1600-0838.2011.01341.x

35.Posner JD, Gorman KM, Windsor-Landsberg L, Larsen J, Bleiman M, Shaw C, Rosenberg B., Knebl J. Low to moderate intensity endurance training in healthy older adults: physiological responses after four months. Journal of the American Geriatrics Society. 1992; 40(1): 1-7. https://doi.org/10.1111/j.1532-5415.1992.tb01820.x

36.Vigelsno A, Gram M, Wiuff C, Andersen JL, Helge JW, Dela F. Six Weeks' Aerobic Retraining After Two Weeks' Immobilization Restores Leg Lean Mass and Aerobic Capacity But Does Not Fully Rehabilitate Leg Strength in Young and Older Men. Journal of Rehabilitation Medicine. 2015; 47(6): 552-560. https://doi.org/10.2340/16501977-1961

37.Lovell DI, Cuneo R, Wallace J, McLellan C. The hormonal response of older men to sub-maximum aerobic exercise: The effectoftraininganddetraining. Steroids.2012;77(5):413-418. https://doi.org/10.1016/j.steroids.2011.12.022

38. Wwlls CL. Women, sport \& performance. Human Kinetics, 1991.

39. Standley R, Harber M, Lee J, Konopka A, Trappe S, Trappe T. Influence of aerobic cycle exercise training on patellar tendon cross-sectional area in older women. Scandinavian Journal of Medicine \& Science in Sports. 2013; 23(3): 367-373. https://doi.org/10.1111/j.1600-0838.2011.01396.x

40.Spina RJ, Ogawa T, Kohrt WM, Martin W, Holloszy J, Ehsani A. Differences in cardiovascular adaptations to endurance exercise training between older men and women. Journal of Applied Physiology. 1993; 75(2): 849-855. https://doi.org/10.1152/jappl.1993.75.2.849

41.Coggan AR, Spina RJ, King DS, Rogers MA, Brown M, Nemeth P, Holliszy J. Skeletal muscle adaptations to endurance training in 60-to 70-yr-old men and women. Journal of Applied Physiology. 1992; 72(5): 1780-1786. https://doi.org/10.1152/jappl.1992.72.5.1780

42.Coyle EF, Martin WR, Sinacore DR, Joyner MJ, Hagberg JM, Holloszy JO. Time course of loss of adaptations after stopping prolonged intense endurance training. Journal of Applied Physiology. 1984; 57(6): 1857-1864. https://doi.org/10.1152/jappl.1984.57.6.1857

43. Yassine HN, Marchetti CM, Krishnan RK, Vrobel TR, Gonzalez F, Kirwan JP. Effects of exercise and caloric restriction on insulin resistance and cardiometabolic risk factors in older obese adults - a randomized clinical trial. The Journals of Gerontology Series A: Biological Sciences and Medical Sciences. 2009; 64A(1): 90-95. 
https://doi.org/10.1093/gerona/gln032

44.Nuttamonwarakula A, Amatyakul S, Suksom D. Twelve weeks of aqua-aerobic exercise improve health-related physical fitness and glycemic control in elderly patients with type 2 diabetes. Journal of Exercise Physiology Online. 2012; 15(2): 64-71.

45.Nuttamonwarakula A, Amatyakul S, Suksom D. Effects of water-based versus land-based exercise training on cutaneous microvascular reactivity and C-reactive protein in older women with type 2 diabetes mellitus. Journal of Exercise Physiology Online. 2014; 17(4): 27-34.

46.Broman G, Quintana M, Lindberg T, Jansson E, Kaijser L. 2006: High intensity deep water training can improve aerobic power in elderly women. European
Journal of Applied Physiology. 2006; 98(2): 117-123. https://doi.org/10.1007/s00421-006-0237-2

47.Coker RH, Williams RH, Kortebein PM, Sullivan $\mathrm{DH}$, Evans WJ. Influence of exercise intensity on abdominal fat and adiponectin in elderly adults. Metabolic Syndrome and Related Disorders. 2009; 7(4): 363-368. https://doi.org/10.1089/met.2008.0060

48.Duffy KB. Investigating the effects of a 6-month aerobic exercise intervention on brain function and memory in older adults. MSc Thesis. University of Illinois at UrbanaChampaign, 2016.

49.Vitiello MV. Sleep disorders and aging: understanding the causes. The Journals of Gerontology. 1996;52: 189-91. https://doi.org/10.1097/00001504-199607000-00011

\section{Information about the authors:}

Nikola Aksović; https://orcid.org/0000-0002-5312-3456; nicifor007@outlook.com; Faculty of Sport and Physical Education, University of Niš, Serbia.

Bojan Bjelica; (Corresponding author); https://orcid.org/0000-0001-5539-8210; nicifor007@outlook.com; Faculty of Sport and Physical Education, University of East Sarajevo, Bosnia and Herzegovina.

Marko Joksimović; http://orcid.org/0000-0003-4232-5033; nicifor007@outlook.com; Football club National, Ljajkovići bb, 81000 Podgorica, Montenegro.

Iryna Skrypchenko; http://orcid.org/0000-0001-5895-3099; sit71@ukr.net; Dnipropetrovs'k State University of Internal Affairs; Dnipro, Ukraine.

Siniša Filipović; https://orcid.org/0000-0001-7282-9473; nicifor007@outlook.com; School of Medicine, University of Belgrade, Serbia.

Filip Milanović; https://orcid.org/0000-0002-9527-5204; nicifor007@outlook.com; School of Medicine, University of Belgrade, Serbia.

Bojan Pavlović; https://orcid.org/0000-0002-4951-4542; Fnicifor007@outlook.com; aculty of Sport and Physical Education, University of East Sarajevo, Bosnia and Herzegovina.

Bojan Ćorluka; https://orcid.org/0000-0003-3087-5206; Fnicifor007@outlook.com; aculty of Philosophy, University of East Sarajevo, Bosnia and Herzegovina.

Radomir Pržulj; https://orcid.org/0000-0003-4931-4898; nicifor007@outlook.com; Faculty of Sport and Physical Education, University of East Sarajevo, Bosnia and Herzegovina.

Cite this article as:

Aksović N, Bjelica B, Joksimović M, Skrypchenko I, Filipović S, Milanović F, Pavlović B, Ćorluka B, Pržulj R. Effects of aerobic physical activity to cardio-respiratory fitness of the elderly population: systematic overview. Pedagogy of physical culture and sports, 2020;24(5):208-218.

https://doi.org/10.15561/26649837.2020.0501

This is an Open Access article distributed under the terms of the Creative Commons Attribution License, which permits unrestricted use, distribution, and reproduction in any medium, provided the original work is properly cited (http://creativecommons.org/licenses/by/4.0/deed.en).

Received: 26.02 .2020

Accepted: 27.03.2020; Published: 30.10.2020 